\title{
Validation of Nursing Diagnoses for people with chronic kidney conditions on conservative treatment
}

\author{
Validação de Diagnósticos de Enfermagem para pessoas em condições renais \\ crônicas em tratamento conservador \\ Validez de Diagnósticos de Enfermería para personas en condiciones renales \\ crónicas en tratamiento conservador
}

How to cite this article:

Menezes HF, Camacho ACLF, Sousa PAF, Primo CC, Ferreira LB, Silva RAR. Validation of Nursing Diagnoses for people with chronic kidney conditions on conservative treatment. Rev Esc Enferm USP. 2021;55:e20200396. doi: http://dx.doi.org/10.1590/1980-220X-REEUSP-2020-0396

(D) Harlon França de Menezes ${ }^{1}$
(D) Alessandra Conceição Leite Funchal
Camacho $^{1}$
(D) Paulino Artur Ferreira de Sousa ${ }^{2}$
(D) Cândida Caniçali Primo
(D) Lucas Batista Ferreira ${ }^{4}$
(D) Richardson Augusto Rosendo da
Silva $^{4}$

${ }^{1}$ Universidade Federal Fluminense, Escola de Enfermagem Aurora de Afonso Costa, Niterói, RJ, Brazil.

${ }^{2}$ Escola Superior de Enfermagem do Porto, Porto, Portugal.

${ }^{3}$ Universidade Federal do Espírito Santo, Vitória, ES, Brazil.

${ }^{4}$ Universidade Federal do Rio Grande do Norte, Departamento de Enfermagem, Natal, RN, Brazil.

\section{ABSTRACT}

Objective: To develop and validate Nursing Diagnoses statements of the International Classification for Nursing Practice (ICNP ${ }^{\circledR}$ ) aimed at the care of people with chronic kidney conditions undergoing conservative treatment. Method: This is a methodological research structured in sequenced construction stages, cross-mapping, content validation by the Delphi Technique by specialist nurses, and categorization of Nursing Diagnoses. Results: Forty-two specialist nurses participated in the first round and 34 in the second. A total of 179 Nursing Diagnoses statements were prepared, categorized according to Roy's adaptation model, of which 160 were validated for content, with Content Validity Index $\geq 0.80$. Conclusion: The Diagnoses developed and validated show the modes of adaptation to health of people with chronic kidney conditions undergoing conservative treatment, influenced by biological, psychological, social, and cultural needs, with the Physiological Mode being the most prevalent.

\section{DESCRIPTORS}

Renal Insufficiency, Chronic; Nursing Diagnosis; Standardized Nursing Terminology; Classification; Conservative Treatment. 


\section{INTRODUCTION}

Chronic Kidney Disease (CKD) is recognized as a worldwide public health problem ${ }^{(1-2)}$ which, to be confronted, requires the organization of assistance, as well as the effectiveness of treatment ${ }^{(3)}$.

Conservative treatment, which seeks to reduce CKD rate of progression, requires adaptations ${ }^{(4)}$. In view of this, the nurse has an important role in the identification of significant stimuli and problems for the implementation of care, contributing to the identification of the affected needs. In this perspective, the Adaptation Model, by Callista Roy, is adequate, as it understands that the person needs to go through a process of adaptation to their new health and disease conditions, being demanded for adaptive response that affects human biopsychosocial individuality ${ }^{(5-6)}$.

According to the Model, the behaviors resulting from the coping processes can be observed in four adaptive modes (physiological-physical, self-concept-group identity, role performance and interdependence) and the nurse is responsible for encouraging adaptation and improving the interaction of the systems with the environment, promoting health through the Nursing Process (NP) ${ }^{(7)}$.

In this respect, the relevance of using standardized language systems in the NP stands out, since they allow interdisciplinary communication, facilitate the assessment of the quality of care, promote patient safety, and provide the development of Nursing as a science ${ }^{(8)}$.

The International Classification for Nursing Practice $\left(\mathrm{ICNP}^{\circledR}\right)$ composes a standardized language, in which its structure of terms and definitions allows the collection, description, and documentation of the Nursing phenomena, namely: nursing diagnoses, results, and interventions. Furthermore, studies relating the formulation of Diagnoses, using $\mathrm{ICNP}^{\circledR}$, are fundamental to the nurses' clinical practice $^{(9)}$.

Therefore, the present study aims to develop and validate, in terms of content, Nursing diagnoses of ICNP ${ }^{\circledR}$ aimed at the care of people with chronic kidney conditions undergoing conservative treatment.

\section{METHOD}

\section{Design of Study}

This is a methodological study followed by content validation using the Delphi technique. It was held between January and May 2020, divided into six steps: 1) Integrative literature review, with identification of terms related to care of chronic kidney conditions patients on conservative treatment; 2) Elaboration of specialized terminology and Mapping of terms identified with the terms of $\mathrm{ICNP}^{\circledR}$, version 2019, and identification of adaptive problems; 3) Elaboration of the Nursing Diagnoses statements; 4) Construction of conceptual and operational definitions; 5) Categorization of Diagnoses according to the Roy Model; and 6) Content validation.

\section{Construction of the Analysis Corpus}

The study was started with an integrative review through the databases: Medical Literature Analysis and Retrieval System Online (MEDLINE), Latin American and Caribbean Health Sciences Information Literature (LILACS), Cumulative Index to Nursing and Allied Health Literature (CINAHL), Brazilian Nursing Database (BDENF), Scientific Electronic Library Online (SCIELO) and Scopus. Medical Subject Headings (Mesh) descriptors were used: "Renal Insufficiency, Chronic" and "Conservative Treatment", crossed, simultaneously, with the Boolean operator "AND". The following inclusion criteria were used: publications in Portuguese, English or Spanish, with no time limits; and to have clinical indicators of human responses of chronic kidney disease patients on conservative treatment. Editorials and reflection studies were excluded.

The publications underwent a process of removal of sections with low potential for relevant terms, such as titles, authors, pieces of information about the authors, abstracts, footnotes, methodology, references, and acknowledgments. After these extractions, the essential content was grouped into a single file in $\mathrm{Word}^{\circledR}$ format, which was converted to a portable document format (PDF).

Then, the terms were extracted using the computational tool PorOnto, which processes information using large-scale ontologies $^{(10)}$, resulting in a list of terms organized in order of occurrence, arranged in an Excel $^{\circledR}$ spreadsheet. As PorOnto is a tool for building ontologies from texts in Portuguese, articles in other languages have been translated by specialized professionals.

Among the extracted terms, nouns, adjectives, and verbs were used based on the frequency of appearance and relationship with the theme of the study. Subsequently, the selected terms were normalized and refined as to the standardization of gender, number, degree, and verbal inflections, with the purpose of identifying and removing repetitions. Then, the standardized terms were subjected to the mapping technique, which allowed crossing with the terms from ICNP ${ }^{\circledR}$, version 2019 , using the software Microsoft Office Access ${ }^{\circledR} 2010$ to identify constant and non-constant terms in this terminology. In this phase, the International Standards Organization (ISO) 12300: $2016^{(11)}$ was used. Thus, the behaviors and stimuli associated with these terms were identified, namely, "Adaptive problems", which are broad areas of concern related to adaptation and which describe the difficulties related to the indicators of positive adaptation $^{(7)}$.

Subsequently, Nursing Diagnosis statements were constructed from the term bank consolidated in the previous step, based on the ICNP ${ }^{\circledR} 7$-Axes Model, following the recommendations of the International Council of Nurses (ICN) and ISO 18.104: 2014 ${ }^{(12)}$. Finally, operational definitions (OD) were constructed for all standardized terms, using $\mathrm{ICNP}^{\circledR}$, scientific articles, and Portugueselanguage and technical health terms dictionaries, to 
facilitate validation by specialists. The construction of the OD took place according to the following steps ${ }^{(13)}$ : 1) preliminary definition; 2) literature review; 3) development or identification of specific characteristics; 4) mapping of the concept meaning; and 5) affirmation of the operational definition.

\section{SELECTION OF EXPERTS}

To compose the study population, nurses specialized in the Lattes Platform of the National Council for Scientific and Technological Development (CNPq) were sought, using the term "chronic kidney disease" as subject. In addition, the filters on the homepage were adopted: Educational background/Titles: All; Country: Brazil; Region/State: All, and Professional Practice: Major Area: Health Sciences; Area: Nursing; Subarea: Adult and Elderly Health Nursing; Specialty: All. Inclusion criteria were: nurses with at least a Master's degree, who worked with Nursing Diagnoses and with $\mathrm{ICNP}^{\circledR}$ and/or focused on $\mathrm{CKD}$ in care, teaching and/or research.

To calculate the sample of specialists, the following formula was used: $n=Z^{2} 1-\alpha / 2$. p. $(1-p) / e 2$, where " $Z^{2} 1-\alpha / 2 "=$ confidence level adopted; " $p$ " = expected proportion of specialists; and " $\mathrm{e}$ " = difference in acceptable proportion in relation to what would be expected ${ }^{(14)}$. The 95\% confidence level was adopted $\left(Z^{2} 1-\alpha / 2=\right.$ 1.96), an expected proportion of $85 \%$ of specialists and a sampling error of $15 \%$, resulting in an ideal sample of 22 specialists.

Considering the difficulty of specialists returning for validation studies, it was decided that a larger number of specialists would be invited. The initial search consisted of 535. Following refinement of the established criteria, 56 were invited to participate in the validation, and a return of 42 in the first round and 34 in the second was obtained. Invitation letters, the Free and Informed Consent Form, and a structured form via Google Forms were sent via the Web. The time for answers was 30 days.

\section{Data Analysis and Treatment}

The Nursing Diagnoses elaborated were adjusted as to the spelling, based on the statements contained in the $\mathrm{ICNP}^{\circledR}$, and distributed in the four Modes, according to the Roy Model ${ }^{(15)}$. For data analysis, the Content Validity Index (CVI) was used. Therefore, indices were calculated for the scores attributed by the experts to each ND, based on a five-point Likert scale ( 1 = not pertinent; 2 = slightly pertinent; 3 = very pertinent; 4 = pertinent; 5 = extremely pertinent), with $\mathrm{NDs}$ with $\mathrm{CVI} \geq 0.80$ being validated.

\section{Ethical Aspects}

The ethical precepts of Resolution No. 466/2012, of the National Health Council, were followed. The project was approved by the Human Research Ethics Committee of Universidade Federal Fluminense, under Opinion No. 3.798.213, on Jan 10, 2020.

\section{RESULTS}

A total of 1940 articles was found in the six databases, with 126 publications being excluded because they did not have the abstract available. Thus, 1814 articles were selected for reading of abstracts. Of these, 38 publications were excluded due to duplication and 1723 productions for not meeting the inclusion criteria, with 53 articles being left and composing the review, with 23 in Portuguese, 24 in English, and six in Spanish.

After PorOnto's reading, 19,367 terms of the publications were extracted. Then, the repetitions were excluded and the terms were subjected to the normalization and uniformization process, with spelling correction, analysis and exclusion of synonyms, adequacy of verb tense, gender and number, with a total of 957 relevant terms being consolidated.

The mapping of the 957 terms identified in the literature and the terms of the ICNP ${ }^{\circledR}$ resulted in 499 constant terms and 458 non-constant terms. As for the constant ones, 247 were on the "Focus" axis; 28, on the "Judgment" axis; 34, on the "Means" axis; 100, on the "Action" axis; 28 on the "Time" axis; 50, on the "Location" axis; and 12 on the "Customer" axis. As for the non-constant terms, 250 were on the "Focus" axis; 68, on the "Judgment" axis; 74, on the "Means" axis; 35 on the "Action" axis; 10 on the "Time" axis; 12 on the "Location" axis; and 9 on the "Customer" axis. Regarding the adaptive problems, it was possible to find, from the literature, 73 problems, which are shown in Figure 1.

As for the specialist nurses participating in the content validation, in the two rounds, they were mostly female (95\%), aged between 40 and 45 years (65\%), residents of Southeast Brazil (50\%), working in the higher education (80\%), with a master's degree (55\%).

A total of 179 Nursing Diagnoses statements were prepared, categorized according to Roy's adaptive modes, of which 160 were validated by specialists, for presenting the CVI $\geq 0.80$, as shown in Chart 1 .

Of the diagnoses eliminated, the following can be mentioned: "Risk of Diabetic Foot Ulcer", "Risk of Violence", "Postural Vertigo", "Urinary Incontinence" and "Chest Pain". Changes in the allocation of Diagnoses in the previously established Adaptation Modes were suggested; for example, for the Diagnosis "Learning, Impaired", a change was suggested from the Real Life Function Mode to the Physiological/Neurological Function Mode. For the "Comfort, Impaired" Diagnosis, a change was suggested from the Self-Concept to the Physiological/Activity and Rest Mode, "Musculoskeletal Pain" from the Physiological/Activity and Rest Mode to the Physiological/Senses Mode. 


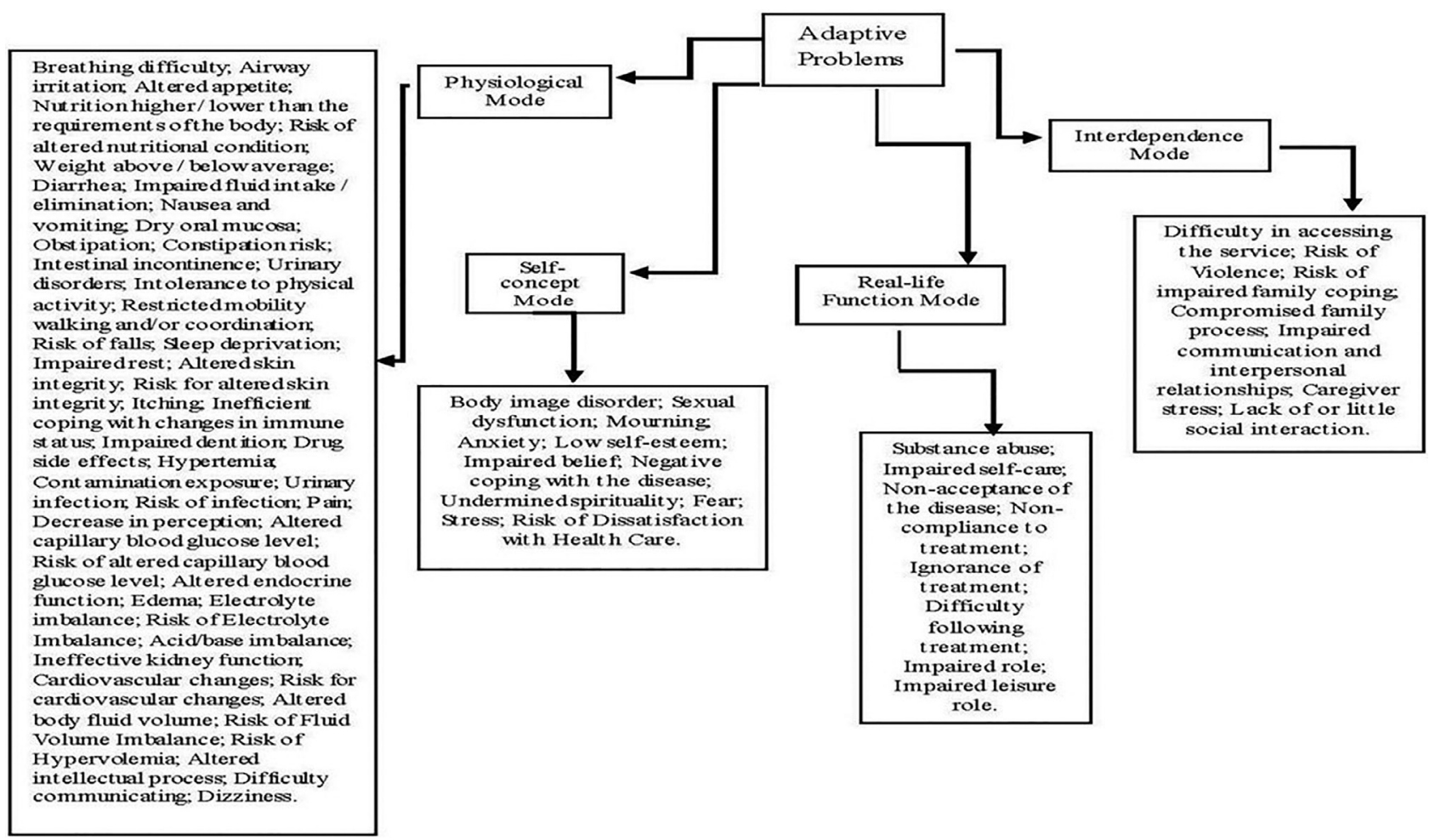

Figure 1 - Distribution of adaptation problems - Niterói, RJ, Brazil, 2020.

Chart 1 - Nursing Diagnoses for chronic kidney disease patients on conservative treatment - Niterói, RJ, Brazil, 2020.

\begin{tabular}{|c|}
\hline NURSING DIAGNOSES (CVI $\geq \mathbf{0 . 8 0})$ \\
\hline PHYSIOLOGICAL MODE \\
\hline 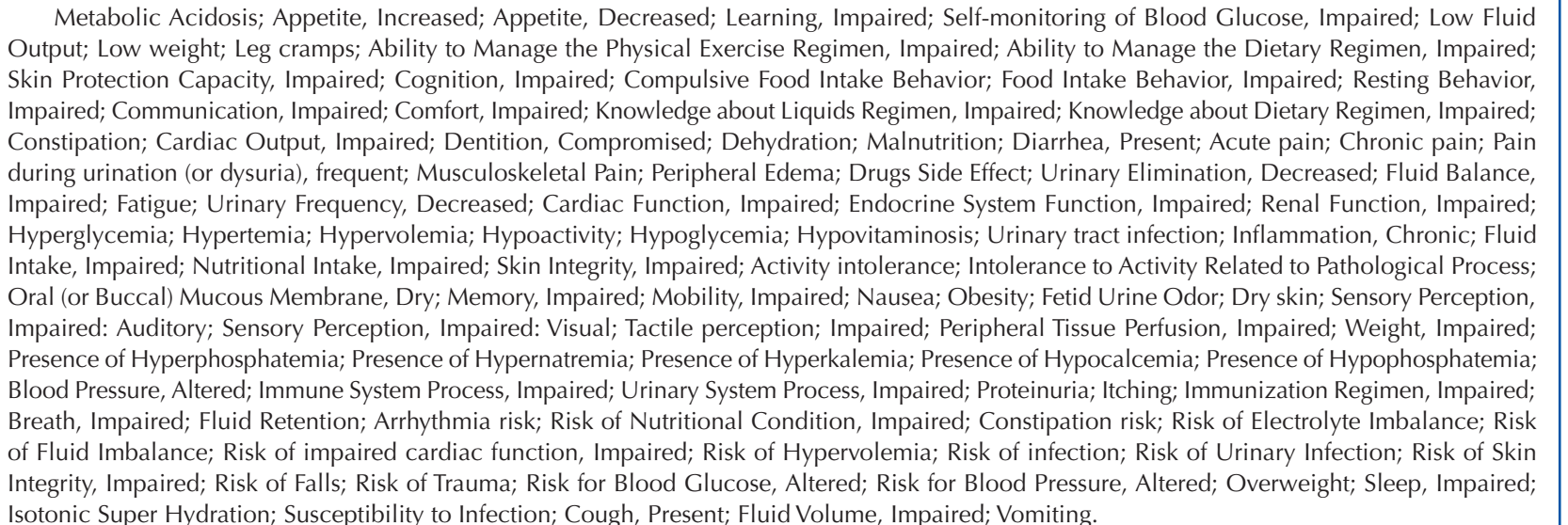 \\
\hline
\end{tabular}

\section{SELF-CONCEPT MODE}

Adaptation, Impaired; Spiritual Distress; Anxiety; Self-esteem, Impaired; Self-image, Negative; Aggressive Behavior; Spiritual Condition, Impaired; Health Belief, Conflicting; Spiritual Belief, Conflicting; Sexual Performance, Impaired; Hopelessness; Difficulty in Coping with the Disease; Stigma, Impaired; Stress; Humor, Depressed; Fear of Death; Fear of Abandonment; Resilience, Impaired; Risk of Dissatisfaction with Health Care; Suffering; Sadness.

\section{REAL LIFE FUNCTION MODE}

Alcohol abuse; Tobacco abuse; Acceptance of the State of Health, Impaired; Compliance to Drug Regimen, Partial; Compliance to the Therapeutic Regimen, Impaired; Ineffective Health Self-Control; Self-Care, Impaired; Low Attendance to Follow-up Consultation; Low Health Knowledge; Ability to Perform Leisure Activity, Impaired; Ability to Manage the Drug Regimen, Impaired; Medication Knowledge, Impaired; Knowledge about fluid Regimen, Impaired; Knowledge about Dietary Regimen, Impaired; Role Performance, Impaired; Difficulty with Drug Regimen, Complex; Expectation about Treatment, Unrealistic; Non-Compliance to the Dietary Regimen; Denial about the Severity of the Disease; Role of Wife (Husband), Impaired; Mother Role, Impaired; Patient Role, Impaired; Father Role, Impaired; Safety Role, Impaired; Labor Role, Impaired; Family Role, Impaired; Care Continuity Problem. 
Access to Treatment, Impaired; Family Ability to Manage the Regimen, Impaired; Communication between the Team and the Individual, Impaired; Communication in the Family, Impaired; Social Condition, Impaired; Caregiver Stress; Lack of Access to Transport; Lack of Family Support; Lack of Social Support; Lack of Trust in the Interprofessional Team; Social isolation; Family Decision Making Process, Impaired; Family Process, Impaired; Risk of Family Coping, Impaired; Marital Satisfaction, Impaired; Socialization, Impaired; Loneliness.

\section{DISCUSSION}

The results demonstrate that most Nursing Diagnoses identified in this study were classified in Roy's physiological mode, which reflects the way the person responds physically to stimuli from the environment. These diagnoses were expressed as a result of the biological changes inherent to the disease process due to CKD, which predispose the person to physical changes that promote chronic illness $^{(16-17)}$.

Therefore, these findings were already expected, because in the theoretical model adopted, this mode gathers the largest number of physical responses to environmental stimuli and that involve the basic needs of the human being that are inherent to physiological integrality (oxygenation, nutrition, elimination, activity and rest, and protection), as well as the four complex processes (neurological and endocrine functions, senses and electrolytes/fluids/acid-base balance). In this regard, the nurse's assistance shall meet the biological needs without, however, neglecting the other dimensions of care that influence the establishment of health ${ }^{(18)}$.

Still within the physiological mode, fluids and electrolytes were the ones that obtained the most Nursing Diagnoses, expressing the magnitude of the biochemical problem caused by CKD. It is known that in the kidney disease progression, the hydroelectrolytic balance can cause electrolyte and metabolic dysfunction, damaging the body's natural function ${ }^{(19)}$.

The monitoring of renal function is closely related to other clinical factors that contribute to the worsening of $\mathrm{CKD}$, as is the case of associated chronic diseases, clinical indicators and unhealthy habits, the main ones being: diabetes, hypertension, proteinuria, anemia, metabolic complications, obesity, smoking, and dyslipidemia. Thus, Nursing Diagnoses related to these adaptive problems have been validated, which is consistent with the importance of strict control of these factors, as this will minimize the progression of the disease and reduce adjacent risks ${ }^{(20)}$.

One of the main changes during conservative treatment concerns nutrition, as it influences all phases of metabolism and plays a major role in health. Diagnoses such as "Malnutrition" and "Knowledge about Dietary Regimen, Impaired" were validated, which highlight adaptive problems and reflect the need for adjustments in the diet as a strategy to balance the symptoms of $\mathrm{CKD}^{(21)}$.

The assessment of the nutrition status is an important nursing action in promoting adaptation and health. By this means, it promotes individualized care, encompassing the Nursing Diagnoses present in each person and thus providing care directed to their true affected health needs ${ }^{(5-7)}$. Therefore, the physiological mode gives the nurse an indication of how the person is dealing with the environmental changes that affect the physiological resistance mechanisms.

Nursing Diagnoses that fit the psychosocial adaptation modes were also validated. It is known that people with chronic conditions experience processes of personal change, resulting from limitations, frustrations, and losses, which thus require changes in daily behaviors in the roles and activities they perform, that is, changes that impact on a new management of their lives ${ }^{(22)}$.

The Self-Concept Mode focuses specifically on the psychological and spiritual aspects of the person, being a composite of beliefs and feelings that the person has about $\mathrm{him} /$ herself and is formed from inner perceptions and the perceptions of others ${ }^{(7)}$. Diagnoses such as "Distress", "Anxiety" and "Depression" were validated, which reflect this reality and are frequent in people with CKD. Furthermore, these Diagnoses can cause difficulties in managing and coping with the illness ${ }^{(16)}$.

Moreover, depressive symptoms can be correlated with a higher risk of complications related to the burden of associated diseases, symptoms and functional dependence, increased morbidity and mortality, poor therapeutic and dietary compliance and impaired quality of life, making the incidence of suicide ten times greater compared to the general population $^{(23)}$. The self-concept mode is based on the person's psychic and spiritual integrity aspects, that is, it is based on patterns of beliefs, values, and emotions. Such aspects can be accessed by nurses when they understand that it is important to determine the abilities of the individuals with chronic kidney conditions of feeling and experiencing themselves as physical beings.

In the psychosocial mode of Function in real life or role function, Diagnoses were validated, which specifically focus on the roles that the person has in society. Thus, if the person is experiencing a problem related to the role he or she plays, the effects can be manifested in the ability to heal and maintain health ${ }^{(7)}$.

Treatment conditions and the chronic progression of the disease affect the quality of life of people with chronic kidney conditions, since they trigger burnout, limit the possibility of doing physical activities, cause dependency and unstable feelings regarding health and well-being, resulting in depressive symptoms and low medication and nutritional compliance. Therefore, the nurse shall recognize, in the individuality of the person with chronic kidney conditions, the understanding about their illness and its personal and social impact, since this condition brings changes to life habits. Nurses also have to realize that 
preventive measures are required and shall be implemented to reverberate throughout life ${ }^{(24-25)}$.

With regard to interpersonal relationships, people undergoing treatment for CKD reveal that the married marital status was more comfortable compared to the single status. Family and spouse support comprises intense compliance to treatment, because with support, treatment becomes easier to be faced, that is, it reinforces social support and dietary and fluid restrictions compliance ${ }^{(18)}$.

The results of this study point to the consistency presented by ICNP ${ }^{\circledR}$, since it is articulated as a system that gathers terms from different sources and that may be pertinent to the development of concepts of the elements of Nursing practice. Therefore, the use of the $\mathrm{ICNP}^{\circledR}$ by the nurse contributes to indicate a clinical judgment to the individuals who are under their assistance, since it has a framework that can be improved with indicators of their own experience, thus reflecting on the approximation of scientific knowledge to the reality of practice.

Simultaneously, the adoption of the theoretical model by Callista Roy adopted for the study showed how the Diagnoses can be applied to practice and allied with the conceptual subsidies of the model, leading to a broad view of the behavioral adaptation problems and the scope of recognition of the individual as an adaptable and holistic system.
Among the limitations of the study, it is understood that content validation is a subjective process that requires inductive and deductive skills on the part of specialist nurses.

\section{CONCLUSION}

The study allowed listing 179 ICNP $^{\circledR}$ Nursing Diagnoses oriented to care of people with chronic renal conditions undergoing conservative treatment, of which 160 were validated by experts as to content. The predominant Roy Adaptation modes were the Physiologic Mode and its derivations, followed by the Self-Concept Mode, which portray these people's situations of adaptation to the health, influenced by biological, psychological, social, and cultural needs. Such needs can be affected by the quality of care and the environment to which they are exposed, as well as show foci of attention during treatment, which allows assistance and orientation of systematized, individual, and resolving actions.

It is believed that the Nursing Diagnoses statements developed do not exhaust the domain of this health priority, and further research shall be developed to build and validate a terminological subset for people with chronic kidney conditions undergoing conservative treatment, in the hope of distinguishing the elements of Nursing practice and, thus, put such elements into practice.

\section{RESUMO}

Objetivo: Elaborar e validar enunciados de Diagnósticos de Enfermagem da Classificação Internacional para a Prática de Enfermagem $\left(\mathrm{CIPE}^{\oplus}\right)$ voltados para o cuidado de pessoas em condições renais crônicas em tratamento conservador. Método: Pesquisa metodológica estruturada em etapas sequenciadas de construção, mapeamento cruzado, validação de conteúdo pela Técnica Delphi por enfermeiros especialistas e categorização dos Diagnósticos de Enfermagem. Resultados: Participaram 42 enfermeiros especialistas na primeira rodada e 34 na segunda. Foram elaborados 179 enunciados de Diagnósticos de Enfermagem, categorizados segundo os modos adaptativos de Roy, dos quais 160 foram validados quanto ao conteúdo, com Índice de Validade de Conteúdo $\geq 0.80$. Conclusão: Os Diagnósticos elaborados e validados retratam os modos de adaptação à saúde de pessoas em condições renais crônicas em tratamento conservador, influenciadas por necessidades biológicas, psicológicas, sociais e culturais, sendo o Modo Fisiológico o mais predominante.

\section{DESCRITORES}

Insuficiência Renal Crônica; Diagnóstico de Enfermagem; Terminologia Padronizada em Enfermagem; Classificação; Tratamento Conservador.

\section{RESUMEN}

Objetivo: Elaborar y validar enunciados de Diagnósticos de Enfermería de la Clasificación Internacional para Práctica de Enfermería $\left(\mathrm{CIPE}^{\circledR}\right)$ orientados al cuidado de personas en condiciones renales crónicas en tratamiento conservador. Método: Investigación metodológica estructurada en etapas secuenciadas de construcción, mapeo cruzado, validación de contenido por la Técnica Delphi por enfermeros expertos y categorización de los Diagnósticos de Enfermería. Resultados: Participaron 42 enfermeros expertos en la primera etapa y 34 en la segunda. Fueron elaborados 179 enunciados de Diagnósticos de Enfermería, categorizados según los modos adaptativos de Roy, de los cuales 160 fueron validados cuanto al contenido, con Índice de Validez de Contenido $\geq 0,80$. Conclusión: Los Diagnósticos elaborados y validados muestran los modos de adaptación a la salud de personas en condiciones renales crónicas en tratamiento conservador que han sido influidas por necesidades biológicas, psicológicas, sociales y culturales, siendo el Modo Fisiológico el que más predominó.

\section{DESCRIPTORES}

Insuficiencia Renal Crónica; Diagnóstico de Enfermería; Terminología Normalizada de Enfermería; Clasificación; Tratamiento Conservador.

\section{REFERENCES}

1. Biljak VR, Grubb A, Guerra IC, Cavalier E, Raymondo S, Sierra-Amor R, et al. The first step in creating national Chronic Kidney Disease (CKD) guidelines: a questionnaire. Biochem Med (Zagreb). 2019;29(3):030301. doi: https://doi.org/10.11613/BM.2019.030301

2. Shahbazi M, Ganji KS, Mirzakhani M, Mohammadnia-Afrouzi M, Akbari R. The role of immune response in initiation and progression of chronic kidney disease. Iran J Kidney Dis [Internet]. 2019 [cited 2016 Aug 19];13(5):283-99. Available from: http://www.ijkd.org/index. php/ijkd/article/view/4327/1089 
3. Malta DC, Machado ÍE, Pereira CA, Figueiredo AW, Aguiar LK, Almeida WS, et al. Evaluation of renal function in the Brazilian adult population, according to laboratory criteria from the National Health Survey. Rev Bras Epidemiol. 2019;22 Suppl 2:E190010.SUPL.2. doi: https://doi.org/10.1590/1980-549720190010.supl.2

4. Rocha IA, Silva FVC, Campos TS, Marta CB, Lima RA. O custo do atendimento aos pacientes com Doença Renal Crônica (DRC), em fase não dialítica de um hospital universitário. Rev Online Pesq Cuid Fund. 2018;10(3):647-55. doi: http://dx.doi.org/10.9789/2175-5361.2018. v10i3.647-655

5. Debone MC, Pedruncci ESN, Candido MCP, Marques S, Kusumota L. Nursing diagnosis in older adults with chronic kidney disease on hemodialysis. Rev Bras Enferm. 2017;70(4):800-5. doi: http://dx.doi.org/10.1590/0034-7167-2017-0117

6. Costa CPV, Luz MHBA, Bezerra AKF, Rocha SS. Application of the nursing theory of Callista Roy to the patient with cerebral vascular accident. Rev Enferm UFPE on line. 2016; 10 Supl. 1:352-60. doi: 10.5205/reuol.7901-80479-1-SP.1001sup201622

7. Roy C, Andrews HA. The Roy adaptation model. Stamford: Appleton e Lange; 1999.

8. Morais SCRV, Nóbrega MML, Carvalho EC. Cross-mapping of results and nursing interventions: contribution to the practice. Rev Bras Enferm. 2018;71(4):1883-90. doi: http://dx.doi.org/10.1590/0034-7167-2017-0324

9. Souza Neto VL, Costa RTS, Costa DARS, Belmiro SSDR, Lima MA, Silva RAR. ICNP ${ }^{\circledR}$ diagnoses of people living with aids, and empirical indicators. Rev Bras Enferm. 2019;72(5):1226-34. doi: https://doi.org/10.1590/0034-7167-2017-0850

10. Zahra FM, Carvalho DR, Malucelli A. Poronto: tool for semi-automatic ontology construction in portuguese. J Health Inform [Internet]. 2013 [cited 2016 Aug 19];5(2):52-9. Available from: http://www.jhi-sbis.saude.ws/ojs-jhi/index.php/jhi-sbis/article/view/232/167

11. International Organization for Standardization. ISO 12300: health informatics: principles of mapping between terminological systems. Geneva: ISO; 2016.

12. International Organization for Standardization. ISO 18104: health informatics: categorial structures for representation of nursing diagnoses and nursing actions in terminological systems. Geneva: ISO; 2014.

13. Lenz E. Basic principles of measurement: operationalizing nursing concepts. In: Waltz CF, Strickland OL, Lenz E. Measurement in nursing and health research. $5^{\text {th }}$ ed. New York: Springer; 2017.

14. Lopes MV, Silva VM, Araujo TL. Methods for establishing the accuracy of clinical indicators in predicting nursing diagnoses. Int J Nurs Knowl. 2012;23(3):134-9. doi: 10.1111/j.2047-3095.2012.01213.x

15. Hamadé DCE, Moraes CS, Martins MOD, Costa CCP. Nursing diagnoses with coronary patients in the light of Callista Roy's theory. Rev Fun Care Online. 2020;12:129-36. doi: http://dx.doi.org/10.9789/2175-5361.rpcfo.v12.7137

16. Silva VA, Silva RCF, Trovo MM, Silva MJP. Roy's adaptation model and the dual process model of grieving substantiating palliative nursing care to the family. Mundo Saúde. 2017;40A:521-36. doi: 10.15343/0104-7809.201740A521536

17. Brasil. Ministério da Saúde; Secretaria de Atenção à Saúde, Departamento de Atenção Especializada e Temática. Diretrizes Clínicas para o cuidado ao paciente com Doença Renal Crônica - DRC no Sistema Único de Saúde. Brasília; 2014.

18. Melo GAA, Aguiar LL, Silva RA, Quirino GS, Pinheiro AKB, Caetano JA. Factors related to impaired comfort in chronic kidney disease patients on hemodialysis. Rev Bras Enferm. 2019;72(4):889-95. doi: http://dx.doi.org/10.1590/0034-7167-2018-0120

19. Spigolon DN, Teston EF, Souza FO, Santos B, Souza RR, Moreira Neto A. Nursing diagnoses of patients with kidney disease undergoing hemodialysis: a cross-sectional study. Rev Bras Enferm. 2018;71(4):2014-20. doi: http://dx.doi.org/10.1590/0034-7167-2017-0225

20. Castro MCM. Conservative management for patients with chronic kidney disease refusing dialysis. J Bras Nefrol. 2019;41(1):95-102. doi: http://dx.doi.org/10.1590/2175-8239-jbn-2018-0028

21. Bousquet-Santos K, Costa LG, Andrade JMDL. Estado nutricional de portadores de doença renal crônica em hemodiálise no Sistema Único de Saúde. Ciênc Saúde Coletiva. 2019;24(3):1189-99. doi: https://doi.org/10.1590/1413-81232018243.11192017

22. Souza Júnior EV, Brito SA, Rosa RS, Boery EN, Boery RNSO. Impact of factors associated with depressive symptoms on elderly health with hemodialysis. Enferm Actual. 2018;(35):159-72. doi: http://dx.doi.org/10.15517/revenf.v0i35.31519

23. Pretto CR, Rosa MBC, Dezordi CM, Benetti SAW, Colet CF, Stumm EMF. Depression and chronic renal patients on hemodialysis: associated factors. Rev Bras Enferm. 2020;73 Suppl 1:e20190167. doi: http://dx.doi.org/10.1590/0034-7167-2019-0167

24. Ramírez-Perdomo CA, Solano-Ruíz MC. Social construction of the experience of living with chronic kidney disease. Rev Latino Am Enfermagem. 2018;26:e3028. doi: http://dx.doi.org/10.1590/1518-8345.2439.3028

25. Pretto CR, Winkelmann ER, Hildebrandt LM, Barbosa DA, Colet CF, Stumm EMF. Quality of life of chronic kidney patients on hemodialysis and related factors. Rev Latino Am Enfermagem. 2020;28:e3327. doi: http://dx.doi.org/10.1590/1518-8345.3641.3327 